\title{
Long-Term Stability of 5-Fluorouracil in 0.9\% Sodium Chloride after Freezing, Microwave Thawing, and Refrigeration
}

\author{
Laurence Galanti, Massin P Lebitasy, Jean-Daniel Hecq, Julie Cadrobbi, Danielle Vanbeckbergen, \\ and Jacques Jamart
}

\begin{abstract}
Objective: To investigate the stability of 5-fluorouracil diluted in $0.9 \%$ sodium chloride (normal saline [NS]) after freezing, microwave thawing, and storage for 28 days at $5^{\circ} \mathrm{C} \pm 3^{\circ} \mathrm{C}$.

Methods: Polyvinylchloride (PVC) infusion bags $(n=5)$ containing 5-fluorouracil $800 \mathrm{mg} / 100 \mathrm{~mL}$ were frozen for 79 days at $-20^{\circ} \mathrm{C}$. The bags were then thawed in a microwave oven and stored at $5^{\circ} \mathrm{C} \pm 3^{\circ} \mathrm{C}$ for 28 days. The concentration of 5-fluorouracil was measured by highperformance liquid chromatography. Visual and microscopic inspections were performed and $\mathrm{pH}$ was measured periodically during storage. Solutions were considered stable if the lower limit of the $95 \%$ confidence interval of the concentration versus time profile remained greater than $90 \%$ of the initial concentration.
\end{abstract}

Results: No colour change or precipitation was observed in any of the solutions. Slight changes in $\mathrm{pH}$ were observed during refrigeration. 5-Fluorouracil solutions were stable during storage at $5^{\circ} \mathrm{C} \pm 3^{\circ} \mathrm{C}$ for 28 days, as indicated by the results of high-performance liquid chromatography.

Conclusion: 5-Fluorouracil $8 \mathrm{mg} / \mathrm{mL}$ in NS may be prepared in advance, frozen and stored in PVC bags, and thawed before use. The solutions remained stable after freezing at $-20^{\circ} \mathrm{C}$ for 79 days followed by storage at $5^{\circ} \mathrm{C} \pm 3^{\circ} \mathrm{C}$ for up to 28 days.

Key words: 5 -fluorouracil, freezing, thawing, stability, microwave

Can J Hosp Pharm 2009;62(1):34-38

\section{RÉSUMÉ}

Objectif : Analyser la stabilité de solutions de 5-fluorouracile dilué dans du chlorure de sodium à $0,9 \%$ (solution physiologique salée) une fois congelées, puis décongelées au micro-ondes, et entreposées pendant 28 jours à $5^{\circ} \mathrm{C} \pm 3{ }^{\circ} \mathrm{C}$.

Méthodes : Des solutions de 5-fluorouracile à raison de $800 \mathrm{mg}$ dans $100 \mathrm{~mL}$ ont été préparées dans des sacs de polychlorure de vinyle (PVC) pour perfusion $(\mathrm{n}=5)$ qui ont été congelés pendant 79 jours à $-20^{\circ} \mathrm{C}$. Les sacs ont ensuite été décongelés au micro-ondes, puis entreposés à $5^{\circ} \mathrm{C} \pm 3{ }^{\circ} \mathrm{C}$ pendant 28 jours. La concentration du 5 -fluorouracile a été mesurée par chromatographie liquide à haute performance. Des inspections visuelles et microscopiques ont été pratiquées et le $\mathrm{pH}$ mesuré périodiquement pendant la période d'entreposage. Les solutions étaient considérées stables si la limite inférieure de l'intervalle de confiance à $95 \%$ de la courbe de la concentration en fonction du temps demeurait supérieure à $90 \%$ de la concentration initiale.

Résultats : Aucun changement de couleur ni précipité n'ont été observés dans aucune des solutions. De légers changements de $\mathrm{pH}$ ont été notés pendant la période de réfrigération. Les solutions de 5-fluorouracile étaient stables lorsqu'elles étaient entreposées à $5{ }^{\circ} \mathrm{C} \pm 3{ }^{\circ} \mathrm{C}$ pendant 28 jours, comme l'ont montré les résultats de la chromatographie liquide à haute performance.

Conclusion : Les solutions de 5 -fluorouracile à $8 \mathrm{mg} / \mathrm{mL}$ dans une solution physiologique salée peuvent être préparées à l'avance, congelées et conservées dans des sacs en PVC, puis décongelées avant l'utilisation. Les solutions demeurent stables après avoir été congelées à une température de $-20{ }^{\circ} \mathrm{C}$ pendant 79 jours, puis entreposées à $5{ }^{\circ} \mathrm{C} \pm$ $3^{\circ} \mathrm{C}$ jusqu’à 28 jours.

Mots clés : 5-fluorouracile, congélation, décongélation, stabilité, micro-ondes

[Traduction par l'éditeur] 


\section{INTRODUCTION}

5 -Fluorouracil, an analogue of the pyrimidine uracil and one of the oldest anticancer agents, acts as an antimetabolite drug. ${ }^{1}$ It remains the standard therapy for advanced colorectal cancer and is also one of the primary agents used to treat head, neck, and breast cancer. ${ }^{2}$ The drug is usually diluted for parenteral injection with $0.9 \%$ sodium chloride (NS) or $5 \%$ dextrose. ${ }^{3}$

Preparation of IV solutions by a centralized IV additive service has several potential benefits, including efficient and timely preparation and administration of drugs, reduction in medication errors, better health and safety control, high assurance of stability and sterility, and standardization of drug concentration. ${ }^{4}$ Freezing prepared solutions in ready-to-use formats can extend the long-term stability of injectable drugs. ${ }^{5}$ The use of a microwave oven reduces the time required to thaw frozen infusion solutions. ${ }^{6-15}$

The stability of 5-fluorouracil has been tested in several solutions and containers and at various temperatures ranging from $4^{\circ} \mathrm{C}$ to $35^{\circ} \mathrm{C}$. 5-Fluorouracil was stable when prepared in NS and stored in polyolefin bags at $5^{\circ} \mathrm{C} \pm 3^{\circ} \mathrm{C}$ for 28 days. ${ }^{16}$ The purpose of the current study was to evaluate the stability of 5-fluorouracil diluted in NS (800 mg in $100 \mathrm{~mL}$ ) in polyvinylchloride (PVC) bags, frozen for 79 days at $-20^{\circ} \mathrm{C}$, thawed in a microwave oven, and stored for a further 28 days at $5^{\circ} \mathrm{C} \pm 3^{\circ} \mathrm{C}$.

\section{MATERIALS AND METHODS Preparation of Solutions}

5-Fluorouracil (Fluracedyl, $1000 \mathrm{mg}$ in $20 \mathrm{~mL}$; Teva Pharma Belgium SA Wilrijk, Belgium, lot 06 H 28 PA) was diluted in $100 \mathrm{~mL}$ NS in a PVC bag (Macopharma Benelux, Mouscron, Belgium, lot 07 F 08 D, expiry June 2009) to obtain an approximate final concentration of $800 \mathrm{mg} / 100 \mathrm{~mL}$ $(8 \mathrm{mg} / \mathrm{mL}){ }^{17}$ Five such bags were prepared under aseptic conditions in a vertical laminar air flow hood.

\section{Stability Study}

The 5 infusion bags containing 5-fluoruracil $800 \mathrm{mg} / 100$ $\mathrm{mL}$ were frozen (freezer model GS5203, 520 1, Liebherr Comfort, Lienz, Austria) at $-20^{\circ} \mathrm{C}$ in 2 steps. During the freezing step, which took place over the first $24 \mathrm{~h}$, the bags were placed in the freezer until the contents reached the desired temperature of $-20^{\circ} \mathrm{C}$. For the storage step, the bags were moved to a second, identical freezer, which contained only the frozen infusion bags, and were stored for 79 days. After this storage period the bags were thawed at $270 \mathrm{~W}$ power in a carousel-equipped microwave oven (model NND998C/W with specifications 230 V, 800 W, $2450 \mathrm{MHz}$; Panasonic, Saint-Denis, France), according to a validated "light cycle" as previously described..$^{7-15}$ Briefly, this method consists of thawing for $13 \mathrm{~min}$, mixing, and thawing for an additional $7 \mathrm{~min}$. The bags were then stored at $5^{\circ} \mathrm{C} \pm 3^{\circ} \mathrm{C}$ for 28 days.

Immediately after preparation of the bags and again immediately after thawing (designated as day 0), a $2-\mathrm{mL}$ sample of the solution was withdrawn from each of the 5 bags for determination of 5-fluouracil content. Samples were also withdrawn after $1,2,5,7,9,12,15,21$, and 28 days of storage at $5^{\circ} \mathrm{C} \pm 3^{\circ} \mathrm{C}$. Each sample was withdrawn by means of a $2-\mathrm{mL}$ single-use sterile syringe (Terumo, Leuven, Belgium, batch numbers 0610004 and 0707007), equipped with a needle, and was placed in a glass container. The concentration of 5-fluorouracil was determined in triplicate for each sample.

Before sampling, each bag was inspected visually in room light without special equipment, and the colour and appearance of the solution and presence of any precipitate were recorded. A drop of the sample was placed under a cover slip and checked microscopically for crystallization at $100 \times$ magnification (model 4653549 microscope, Carl Zeiss, Oberkochen, Germany) immediately after preparation and after thawing. NS was used as the control solution.

The $\mathrm{pH}$ of each sample was measured with an Inolab Level $1 \mathrm{pH}$ meter (WTW Gmbh, Weilheim, Germany, batch number 01270007) equipped with a glass electrode (Hamilton Biotrode, Bonaduz, Switzerland, product code 1280809/165) and calibrated with 2 standard solutions (BDH Limited, Poole, England; lot 4345650J for $\mathrm{pH} 4.0$ standard and lot 5082000J for $\mathrm{pH} 7.0$ standard).

\section{5-Fluouracil Assay}

Samples were assayed by high-performance liquid chromatography (HPLC; Alliance model 2695 chromatography system, Waters Corporation, Milford, Massachusetts) with a photodiode array detector (model 996, Waters Corporation) and data acquisition and processing module software (Empower 2 Software, Waters Corporation). We used a reverse-phase C18 column with a guard column (Hypersil ODS [C18] 3- $\mu \mathrm{m}$, catalogue number 9868; guard column [C18] 5- $\mu \mathrm{m}$, catalogue number 96013; Alltech Associates, Inc, Deerfield, Illinois, batch number 3/120/4307). The mobile phase was 5\% methanol (Labscan Ltd, Dublin, Ireland, catalogue number C26C11X, batch number 0190/7) and 95\% aqueous $0.01 \mathrm{~mol} / \mathrm{L}$ potassium dihydrogen phosphate (Merck, Darmstadt, Germany, reference 1.04873.1000), adjusted to $\mathrm{pH} 7.50 \pm 0.05$ with aqueous $5.0 \mathrm{~mol} / \mathrm{L}$ sodium hydroxide (Merck, reference 1.06498). The flow rate was $1 \mathrm{~mL} / \mathrm{min}$. The column temperature was set to $35^{\circ} \mathrm{C}$ and the wavelength to $267 \mathrm{~nm}$. The retention time was about $1.7 \mathrm{~min}$.

Control solutions containing 5-fluorouracil at 4 different concentrations $(5,10,25$, and $35 \mathrm{mg} / \mathrm{mL})$ were assayed to calculate within-day variation. Between-day variation was 
estimated with the calibration solution containing 5-fluorouracil at $7.14 \mathrm{mg} / \mathrm{mL}$.

5-Fluorouracil solutions of $1,5,10,15,25,30$, and $35 \mathrm{mg} / \mathrm{mL}$ in sterile water for injection were prepared for use in evaluating the linearity of the assay.

\section{Assay Validation}

The stability-indicating capability of the chromatographic method was assessed using partially decomposed solutions of the drug. Solutions of 5-fluorouracil $(25 \mathrm{mg} / \mathrm{mL})$ were exposed to 3 different $\mathrm{pH}$ conditions: neutral $\mathrm{pH}$ (8.80); alkaline $\mathrm{pH}$ (11.03), obtained by adding $5 \mathrm{~mol} / \mathrm{L}$ sodium hydroxide; and acidic $\mathrm{pH}$ (1.20), obtained by adding $12 \mathrm{~mol} / \mathrm{L}$ hydrochloric acid. Each of these solutions was heated at $100^{\circ} \mathrm{C}$ for $60 \mathrm{~min}$.

Test samples were diluted (1 in 100) with water for injection (B BraunMedical SA, Diegem, Belgium, lot 7425 A 192). Standard solutions were prepared by diluting $100 \mu \mathrm{L}$ of the commercially available 5-fluorouracil solution (Fluracedyl, $1000 \mathrm{mg}$ in $20 \mathrm{~mL}$ [50 mg/mL]; Teva Pharma Belgium SA, lot $06 \mathrm{H} 28 \mathrm{PA})$ in $600 \mu \mathrm{L}$ water for injection. This solution was diluted again ( 1 in 100) before the assay. A $10-\mu \mathrm{L}$ aliquot of each test solution, along with $10-\mu \mathrm{L}$ aliquots of the standard solutions, was injected onto the chromatograph. All samples were assayed in triplicate. All standard and assay solutions were taken from the same batch and package of 5-fluorouracil. The linearity of the analytical response allowed assay calibration with a single level $(7.14 \mathrm{mg} / \mathrm{mL})$.

\section{Statistical Analysis}

Data are expressed as mean and standard deviation (SD). Linear regression was used to analyze the drug concentration on each day over the study period. After verification of the homogeneity of the slopes of the concentration versus time curve obtained from each of the 5 test solutions, a common regression line was estimated. As recommended by the US Food and Drug Administration, the drug solutions were considered stable if the lower limit of the $95 \%$ confidence interval of this common estimated regression line remained above $90 \%$ of the initial concentration. ${ }^{18}$

\section{RESULTS Assay Validation}

Linear regression analysis of the peak area yielded a correlation coefficient $\left(r^{2}\right)$ of 0.9976 in the range of $1 \mathrm{mg} / \mathrm{mL}$ to $35 \mathrm{mg} / \mathrm{mL}$, which indicates good linearity of the assay. The within-day relative SD values $(n=10)$ were $2.80 \%$ for the $35 \mathrm{mg} / \mathrm{mL}$ control solution, $2.90 \%$ for the $25 \mathrm{mg} / \mathrm{mL}$ control solution, $1.72 \%$ for the $10 \mathrm{mg} / \mathrm{mL}$ control solution, and $0.27 \%$ for the $5 \mathrm{mg} / \mathrm{mL}$ control solution. The between-day precision $(n=11)$ estimated for the standard solution (7.14 $\mathrm{mg} / \mathrm{mL}$ ) was $3.04 \%$.

Degraded samples of 5-fluorouracil were assayed to confirm separation of the parent drug from its degradation products. Before and after heating at $100^{\circ} \mathrm{C}$ for $60 \mathrm{~min}$, no

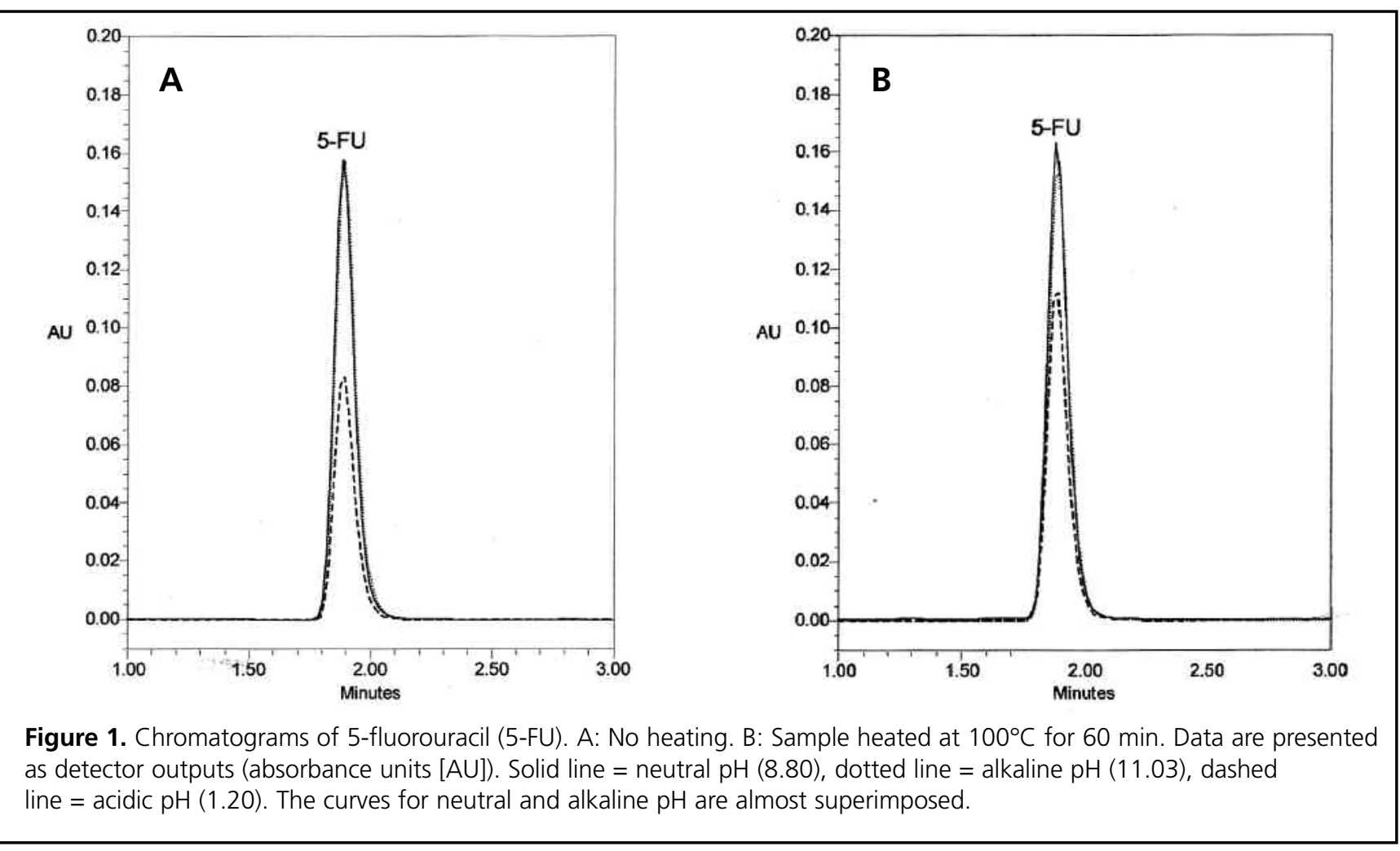


additional peaks from decomposition products were observed, but with acidic $\mathrm{pH}$ there was a decrease in the peak corresponding to the intact drug (Figure 1). Computerized spectral analysis of photodiode array detector signals confirmed the 5-fluorouracil peak.

\section{Stability of 5-Fluorouracil Solutions}

No colour changes or precipitation were observed visually, and no crystallization was observed microscopically after thawing or after 28 days of storage at $5^{\circ} \mathrm{C} \pm 3^{\circ} \mathrm{C}$. The $\mathrm{pH}$ of the solution (mean $\pm \mathrm{SD}$ ) increased slightly over time: the $\mathrm{pH}$ was $8.75 \pm 0.04$ before freezing, $8.86 \pm 0.01$ on day 0 after thawing, and $8.82 \pm 0.01$ on day 28 after thawing, but these changes were not clinically significant, since the solutions remained within the acceptable range for infusion $(4 \leq \mathrm{pH} \leq 10) .{ }^{19}$

The initial concentration of 5 -fluouracil after thawing (day 0 ) and the concentration after various periods of storage, expressed as percentage of the initial concentration, are shown in Table 1. The slopes of the 5 regression lines of the concentration of each bag over time did not differ significantly $(p=0.99)$. The common estimated regression line showed a statistically significant decrease in 5-flurouracil concentration over time $(p<0.001)$. However, the lower limit of the $95 \%$ confidence interval at day 28 remained above $90 \%$ of the initial concentration.

\section{DISCUSSION}

In this study, solutions of 5-fluouracil $8 \mathrm{mg} / \mathrm{mL}$ in NS in PVC bags were stable after freezing and storage for 79 days at $-20^{\circ} \mathrm{C}$, thawing in a microwave oven, and refrigeration for a further 28 days. We believe that the assay was stability- indicating. Although the absence of degradation peaks after heating in acidic and alkaline conditions may indicate that the parent drug remained intact, computer analysis of photodiode array detector signals confirmed the 5-fluorouracil peak by spectral comparison. Other authors have observed the absence of degradation peaks despite a decrease in the peak of the parent drug. ${ }^{20}$

The test concentration of 5-fluorouracil $(8 \mathrm{mg} / \mathrm{mL})$ was chosen because it represents $40 \%$ of the doses $( \pm 5 \%)$ administered in the authors' institution, where a dose-banding technique is used for prescriptions of antineoplastic agents. ${ }^{21}$ With dose-banding, the required dose of an antineoplastic agent is calculated and then rounded up or down to a predetermined dose within a defined range. ${ }^{21}$ Dose-banding with ready-to-use infusions has the potential to increase timely dispensing and administration of antineoplastic agents to patients ${ }^{22}$ without compromising quality and safety. ${ }^{23}$

In this study, only chemical stability was evaluated; each centre must prospectively evaluate the sterility of its own products. However, 5-fluorouracil solutions prepared and stored as described in this study may be assumed to be at low risk of microbiological contamination and safe for administration within 14 days if stored under refrigeration according to USP/NF (United States Pharmacopeia/National Formulary) chapter 797 recommendations. ${ }^{24}$

Standard and test solutions were taken from the same batch and package of commercially available 5-fluorouracil; therefore, the initial drug concentration was assumed to be the same for all test solutions. Overfilling of PVC bags, by up to $28 \%$ for $100-\mathrm{mL}$ bags, ${ }^{8}$ makes it difficult to match the nominal to the expected final concentration, but expressing results as a percentage of the initial concentration permitted us

\section{Table 1. Concentration and pH of 5-Fluorouracil ( $800 \mathrm{mg}$ in $100 \mathrm{~mL} 0.9 \%$ Sodium Chloride) Stored in Polyvinylchloride Bags after Being Frozen and Thawed in a Microwave Oven}

\begin{tabular}{|c|c|c|c|c|}
\hline \multirow{2}{*}{$\begin{array}{l}\begin{array}{l}\text { Storage Time* } \\
\text { (days) }\end{array} \\
0\end{array}$} & \multirow{2}{*}{$\begin{array}{c}\begin{array}{c}\text { Mean Concentration } \\
\pm \mathrm{SD}(\mathrm{mg} / \mathrm{mL}) \dagger\end{array} \\
6.78 \pm 0.12\end{array}$} & \multicolumn{2}{|c|}{$\begin{array}{c}\text { Mean \% of Initial Concentrationः } \\
(95 \% \mathrm{Cl}) \S\end{array}$} & \multirow{2}{*}{$\begin{array}{r}\text { Mean pHף } \pm \text { SD } \\
8.86 \pm 0.01\end{array}$} \\
\hline & & 100.00 & NA & \\
\hline 1 & $6.64 \pm 0.10$ & 99.79 & $99.73-99.85$ & $8.82 \pm 0.01$ \\
\hline 2 & $6.52 \pm 0.12$ & 99.58 & $99.46-99.69$ & $8.84 \pm 0.00$ \\
\hline 5 & $6.37 \pm 0.16$ & 98.94 & $98.65-99.23$ & $8.83 \pm 0.00$ \\
\hline 7 & $6.61 \pm 0.13$ & 98.52 & $98.12-98.92$ & $8.82 \pm 0.01$ \\
\hline 9 & $6.46 \pm 0.10$ & 98.10 & 97.59-98.61 & $8.81 \pm 0.00$ \\
\hline 12 & $6.52 \pm 0.12$ & 97.46 & $96.78-98.14$ & $8.80 \pm 0.00$ \\
\hline 15 & $6.59 \pm 0.11$ & 96.83 & $95.98-97.68$ & $8.85 \pm 0.01$ \\
\hline 21 & $6.46 \pm 0.13$ & 95.56 & $94.37-96.75$ & $8.84 \pm 0.01$ \\
\hline 28 & $6.60 \pm 0.10$ & 94.08 & $92.49-95.66$ & $8.82 \pm 0.01$ \\
\hline
\end{tabular}

$\overline{\mathrm{Cl}}=$ confidence interval, SD = standard deviation.

*Samples were frozen, thawed in a microwave oven, then stored under refrigeration (temperature $5^{\circ} \mathrm{C} \pm 3^{\circ} \mathrm{C}$ )

for the specified periods.

tMean of 5 samples.

\#Initial concentration, before freezing (mean \pm SD): $6.44 \pm 0.15 \mathrm{mg} / \mathrm{mL}$.

$\S$ Based on the profile of concentration versus time obtained by linear regression.

ףlnitial pH, before freezing (mean \pm SD): $8.75 \pm 0.04$ 
to bypass this pitfall. When the entire drug volume within a bag is administered, the overfill volume is considered clinically negligible. ${ }^{25}$

In conclusion, 5-fluorouracil in NS (800 mg in $100 \mathrm{~mL})$ in PVC bags may be frozen for up to 79 days, thawed in a microwave oven, and then stored for up to 28 days at $5^{\circ} \mathrm{C} \pm 3^{\circ} \mathrm{C}$ without major changes in concentration. Advance preparation of batches of 5-fluorouracil IV solutions may therefore be considered. ${ }^{7-15,26-30}$

\section{References}

1. Casale F, Canaparo R, Serpe L, Muntoni E, Pepa CD, Costa M, et al. Plasma concentrations of 5-fluorouracil and its metabolites in colon cancer patients. Pharmacol Res 2004;50(2):173-179.

2. Longley DB, Harkin DP, Johnston PG. 5-Fluorouracil: mechanisms of action and clinical strategies. Nat Rev Cancer 2003;3(5):330-338.

3. Martel P, Petit I, Pinguet F, Poujol S, Astre C, Fabbro M. Long-term stability of 5-fluorouracil stored in PVC bags and in ambulatory pump reservoirs. J Pharm Biomed Anal 1996;14(4):395-399.

4. Koundalijan J. Setting up a CIVAS. In: Needle R, Sizer T, editors. The CIVAS handbook. 1st ed. London (UK): Pharmaceutical Press; 1998. p $1-5$.

5. Vigneron J, Laurelli F, Phaypradith S, Perrin A, Hoffman MA, Hoffman M. [Freezing of solutions for parenteral usage: advantages and disadvantages. Nine months' experience at the pharmacy of Hospital of Nancy]. J Pharm Belg 1992;47(6):504-522. French.

6. Ausman RK, Holmes CJ, Walter CW, Kundsin RB. The application of a freeze-microwave thaw technique to central admixture services. Drug Intell Clin Pharm 1980;14(4):284-287.

7. Hecq JD, Boitquin LP, Vanbeckbergen DF, Jamart J, Galanti LM. Effect of the freezing conditions and microwave thawing power on the stability of cefuroxime in dextrose $5 \%$ infusion polyolefin bags at 4 degrees C. Ann Pharmacother 2005;39(7-8):1244-1248.

8. Boitquin L, Hecq JD, Vanbeckbergen D, Jamart J, Galanti L. Stability of sufentanil citrate with levobupivacaine $\mathrm{HCl}$ in $\mathrm{NaCl} 0.9 \%$ infusion after microwave freeze-thaw treatment. Ann Pharmacother 2004;38(11):1836-1839.

9. Hecq JD, Berlage V, Vanbeckbergen D, Jamart J, Galanti L. Effects of freezing, long-term storage, and microwave thawing on the stability of piperacillin plus tazobactam in 5\% dextrose for infusion. Can J Hosp Pharm 2004;57(5):276-282.

10. Hecq JD, Boitquin LP, Vanbeckbergen DF, Jamart J, Galanti LM. Effect of freezing, long-term storage, and microwave thawing on the stability of ketorolac tromethamine. Ann Pharmacother 2005; 39(10):1654-1658.

11. Hecq JD, Schlesser V, Vanbeckbergen DF, Jamart J, Galanti L. Effects of freezing, long-term storage, and microwave thawing on the stability of cefuroxime sodium in 5\% dextrose infusion polyvinyl chloride bags. Eur J Hosp Pharm Sci 2005;11(1):23-25.

12. Lebrun J, Hecq JD, Vanbeckbergen D, Jamart J, Galanti LM. Effect of freezing, long-term storage and microwave thawing on the stability of tramadol in 5\% dextrose infusion polyvinyl chloride bags. Int J Pharm Compound 2004;8(2):156-159.

13. Rodenbach MP, Hecq JD, Vanbeckbergen D, Jamart J, Galanti L. Effect of freezing, long-term storage, and microwave thawing on the stability of vancomycine hydrochloride in 5\% dextrose infusions. Eur J Hosp Pharm Sci 2005;11(5):111-113.

14. Schlesser V, Hecq JD, Vanbeckbergen DF, Jamart J, Galanti LM. Effect of freezing, long-term storage, and microwave thawing on the stability of cefepime in 5\% dextrose infusion polyvinyl chloride bags. Int J Pharm Compound 2002;6(5):391-394.

15. Hecq JD, Boitquin LP, Lebrun C, Evrard JM, Vanbeckbergen DF, Jamart J, et al. Freeze thaw treatment of ketorolac tromethamine in 5\% dextrose infusion polyolefin bags: effect of drug concentration and microwave power on the long-term stability at $4^{\circ} \mathrm{C}$. Eur J Hosp Pharm Sci 2006;12(4):72-75.
16. Trissel LA. Handbook on injectable drugs. 14th ed. Rockville (MD): American Society of Health-System Pharmacists; 2007. p 736-745.

17. Kleinberg ML, Chang P. Overfill of common piggybag admixture solutions. Hosp Pharm 1984;19:657-658, 662-663, 666-670, passim.

18. Guideline for submitting documentation for the stability of human drugs and biologics. Rockville (MD): US Food and Drug Administration; 1987 [cited 2005 Jul 25). Available from: http://www.fda.gov/ cder//guidance/cmc2.pdf

19. Giraud C, Adam D. Les solutés en perfusion. In: Dauphin A, editor. Pharmascopie soins et thérapies collection. Paris (France): Éditions Arnette; 1998. p 321-331.

20. Trissel LA. The new national standard for sterile preparation. Hosp Pharm 2004;39(9):900-904.

21. Plumridge RJ, Sewell GJ. Dose-banding of cytotoxic drugs: a new concept in cancer chemotherapy. Am J Health Syst Pharm 2001; 58(18):1760-1764

22. MacLean F, MacIntyre J, McDade J, Moyes D. Dose banding of chemotherapy in the Edinburgh Cancer Centre. Pharm J 2003;270(7249):691-693.

23. Baker JP, Jones SE. Rationalisation of chemotherapy services in the University Hospital Birmingham National Health Science Trust. J Oncol Pharm Pract 1998;4(1):10-14.

24. Dine T, Kahlfi F, Duban M, Gressier B, Luyckx M, Brunet C, et al. Effects of PVC bags sterilization process on the 5-fluorouracil stability. Biomaterials 1999;20(7):655-661.

25. Newton DW, Peacock GF, Ballester A, Latif DA. Estimating the volume of prefilled bags of $5 \%$ dextrose injection. Am J Health Syst Pharm 2004;61(12):1281-1285.

26. Cadrobbi J, Hecq JD, Vanbeckbergen D, Jamart J, Galanti L. Long term stability of sodium folinate in dextrose $5 \%$ polyolefin bags at $4^{\circ} \mathrm{C}$. J Oncol Pharm Practice 2007;13(2):99-103.

27. Galanti LM, Hecq JD, Vanbeckbergen D, Jamart J. Long-term stability of cefuroxime and cefazolin sodium in intravenous infusions. J Clin Pharm Ther 1996;21(3):185-189.

28. Galanti LM, Hecq JD, Vanbeckbergen D, Jamart J, Galanti L. Longterm stability of vancomycin hydrochloride in intravenous infusions. J Clin Pharm Ther 1997;22(5):353-356.

29. Galanti LM, Hecq JD, Jeuniau P, Vanbeckbergen D, Jamart J. Assessment of the stability of teicoplanin in intravenous infusions. Int $\mathrm{J}$ Pharm Compound 2001;5(5):397-400.

30. Boitquin L, Hecq JD, Evrard JM, Vanbeckbergen D, Jamart J, Galanti L. Long-term stability of sufentanil citrate with levobupivacaine hydrochloride in $0.9 \%$ sodium chloride infusion PVC bags at $4^{\circ} \mathrm{C}$. J Pain Symptom Manage 2004;28(1):4-6.

Laurence Galanti, MD, PhD, is with the Medical Laboratory, UCL Mont-Godinne, Yvoir, Belgium.

Massin P Lebitasy is a pharmacist with the Medical Laboratory, UCL Mont-Godinne, Yvoir, Belgium.

Jean-Daniel Hecq, PharmD, is a pharmacist with the Hospital Pharmacy, UCL Mont-Godinne, Yvoir, Belgium.

Julie Cadrobbi is a pharmacist with the Medical Laboratory, UCL Mont-Godinne, Yvoir, Belgium.

Danielle Vanbeckbergen is a biologist with the Medical Laboratory, UCL Mont-Godinne, Yvoir, Belgium.

Jacques Jamart, $M D$, is with the Centre de Biostatistique et de Documentation médicale, UCL Mont-Godinne, Yvoir, Belgium.

\section{Address correspondence to:}

Dr Laurence Galanti

Medical Laboratory

UCL Mont-Godinne

1 , avenue Therasse

Yvoir, Namur B-5530

Belgium

e-mail: laurence.galanti@uclouvain.be 